Mill, who retained control until the organization was taken over by the Meteorological Office in 1919. Since then it has continued to flourish with a corps of collaborating observers some five thousand strong. The Royal Meteorological Society has now commemorated Symons's great labours on behalf of science and the nation by affixing to the front wall of his former home in Camden Square a bronze plaque briefly recording his achievements and also his presidency of the Society on two occasions. This plaque was unveiled at noon on August 8 by the Mayor of St. Pancras, Councillor T. J. Redman.

The second ceremony on the same day was the formal opening by Dr. R. C. Sutcliffe, president of the Royal Meteorological Society, of a well-equipped climatological station which the Society, with the friendly co-operation of the St. Pancras Borough Council, has established on a chosen site in the small park of Camden Square. This station replaces one originally set up by Symons at $13 \hat{o}$ Camden Road (250 yards distant) in 1858 and transferred to the garden of his home at 62 Camden Square ten years later. Regular observations were maintained there by Symons and his successors until 1922, and have since been continued (not without difficulty) by the Royal Meteorological Society. These provide the longest unbroken day-to-day record of rainfall, temperature and weather anywhere in the county of London. Quasi-immortality for it is aimed at by the change of site from deteriorating private property more than a century old to an open space under municipal control. The World Meteorological Organization recommends that, for the study of secular climatic change, every nation should strive to keep at least one long-established weather station going in perpetuity. This the Royal Meteorological Society hopes to do at Camden Square.

\section{Dr. Macalister Brew Scholarship Fund}

Tre National Association of Mixed Clubs and Girls' Clubs is establishing a Dr. Macalister Brew Scholarship Fund. Dr. Brew was the Association's education and training adviser for fourteen years. The purpose of the Fund will be to enable young people, less than twenty-five years of age, to secure a term of further education, formal or informal, which they cannot finance themselves and for which no other aid is available. In accordance with the outlook of Dr. Brew, the precise nature of the awards will not be determined in advance but will depend upon needs arising from time to time. Further information about the Fund, together with extracts from some of the many public tributes which have been paid to Dr. Brew, can be obtained from Mr. S. H. Wood, N.A.M.C. and G.C., 30 Devonshire Street, London, W.1, to whom contributions should also be sent, cheques being mado payable to "J.M.B. Scholarship Fund".

\section{The Imperial Institute}

IN reply to a question in the House of Lords on August 1 regarding the Imperial Institute, the Minister of State for Colonial Affairs, the Earl of Perth, replying on behalf of Lord Hailsham, said that a suitable site has been found at the south end of the Holland Park Estate, and negotiations for a building lease, to be heId in the first place by the Minister of Works, are at an advanced stage. The Bill which the Government hopes to introduce early next session will transfer all interests in the land from him to the trustees and will also provide for the cost of the new building to be borne on the Vote for the Ministry of Education. Lord Lloyd and Sir Alan Burns, he said, have accepted invitations to fill the place of the retiring trustees, Lord Brand and Sir Alfred Chester Beatty, and Lord Dundee is succeeding the late Viscount Hudson as chairman of the governing body. It is the intention of the trustees, with the help and advice of the governing body, to press ahead with the planning and erection of the new building. Lord Perth said that there will be no break in the work of the Institute, although some inconvenience will be inevitable. Investigations are still proceeding as to whether, in the development scheme for the Imperial College of Science and Technology, it will be possible to leave the Colleutt tower as a free-standing campanile at a reasonable cost.

In a written reply, Lord Perth gave the names of the trustees of the Imperial Institute, in addition to the two already mentioned, as the Lord President of the Council, the First Commissioner of the Treasury, the President of the Board of Trade, the Minister of Education and Viscount Southbury. The board of governors consists of the chairman, vice-chairman (Sir Griffith Williams), members appointed by the Governments of Canada, New Zealand, Australia, South Africa, India, Pakistan, Ceylon and the Federation of Rhodesia and Nyasaland (usually the High Commissioners or their deputies), nine governors appointed by the Minister of Education and three co-opted members.

\section{Health in British Overseas Territories}

TuE Secretary of State for the Colonies, Mr. Lennox-Boyd, stated in a written reply to a question in the House of Commons on July 30 regarding progress in the elimination of malaria and the treatment of leprosy and malaria during the past decade that malaria had been eliminated in Aden, Antigua, British Guiana (coastal areas), Cyprus, Mauritius, Nevis, St. Kitts, St. Vincent, Santiago and Tobago, and projects for its elimination are in preparation or in progress in British Honduras, Dominica, Grenada Jamaica, North Borneo, Sarawak, St. Lucia, Trinidad and Zanzibar. Prospects in the African territories depend on the results of research and pilot projects in progress. Significant changes in the treatment of leprosy during the past three or four years has resulted in good progress in combating this disease, and provision is increasingly being made, as an alternative to long-term segregation, for out-patient treatment in elinies and rural dispensaries with the sulphene drugs in tablet form. Treatment is increasingly undertaken voluntarily, and in Northern Nigeria there are 468 treatment centres and 104,000 patients under voluntary treatment. Tuberculosis is now regarded as the greatest medical problen in British overseas territories, but in some non-tropical territories, such as Cyprus, Gibraltar and the Falkland Islands, there are indications that the disease is being successfully controlled. B.C.C. vaccination campaigns in Jamaica are beginning to bear fruit, and notification in Trinidad has fallen significantly. Surveys are still being undertaken, particularly in the African territories, with the assistance of the World Health Organization, and increased facilities for treatment have met with a ready response. In Hong Kong, the disease is the greatest single cause of death, but the death-rate is now falling. An 